18. FUNK: UM DISCURSO SEDUTOR DA CULTURA POPULAR

\title{
SESSÃO - 02
}

\section{Vagner Aparecido de Moura*}

\section{Resumo}

O presente artigo aborda o histórico da análise do discurso, formação discursiva -dialogismo e ethos; o conceito de Música e o histórico do estilo Funk, com o propósito de analisar o corpus da música Créu - que contagia os adolescentes da periferia de São Paulo - por meio de um embasamento teórico de Mussalim (2005), Maigueneau (2004), Bakhtin (1992), Kerbrat-Orecchioni (1989), Amossy (2005) e Herschmann (2005).

Palavras-chave: Discurso; cultura; funk ; música

\section{Abstract}

The current paper discusses history of discourse analysis, discursive formation-dialogism and ethos, concept of music history and style of Funk, which infects young people on the outskirts of Sao Paulo, in order to analyze the corpus of creu music, by theoretical basement of Mussalim (2005), Maigueneau (2004), Bakhtin (1992), Kerbrat-Orecchioni (1989), Amossy (2005) \& Herschmann (2005).

Keywords: Discoursive; culture; music; funk

\footnotetext{
* Doutorando pelo Programa de Estudos Pós-Graduados em Ciências Sociais da PUC-SP e graduando em Ciências Sociais pela UNIFESP, Mestre em Língua Portuguesa pela PUC-SP, graduado em História pela UNIMES, em Letras pela UNICID, em Informática com ênfase em gestão de negócios pela UNESP e em Gestão de Negócios internacionais pela UNINOVE. E mail: moura_vagner@ig.com.br
} 


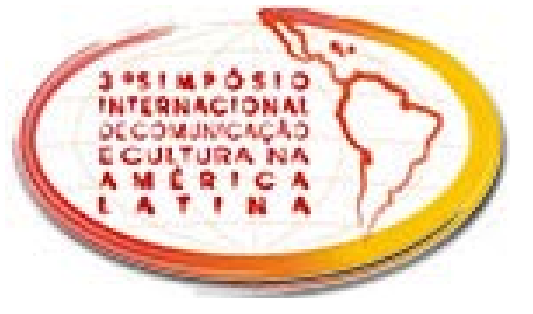

Sessão de Comunicações Coordenadas 02

Cultura, Cidadania e Mídias Alternativas

\section{Considerações preliminares}

A antropologia interpretativa postula que, no estudo dos valores culturais de uma determinada sociedade, não cabe mais a busca de leis universalizantes para o gênero humano, porém uma interpretação das culturas existentes, a sua compreensibilidade por nós, por intermédio de sua tradução ${ }^{1}$, em outras palavras, segundo Jordão (2004, p.38), “o critério de cientificidade deve residir na estruturação lógica da pesquisa, na compreensão do fenômeno estudado e não mais em uma neutralidade e objetividade absolutas do conhecimento".

Partindo desse pressuposto, fomos impelidos a adentrar no ambiente escolar e perceber que o cotidiano escolar é movido por valores, sentimentos, pensamentos, concepções, culturas escolares e profissionais, onde as culturas sociais guiam os agentes, sujeitos da prática educativa, já que é o momento da autodescoberta da ação humana é mais do que a descoberta de explicações causais, teóricas ou ideológicas. Nesse processo de desnudamento da realidade que cerca o cotidiano do adolescente, nota-se que a música exerce um papel fucral no desenvolvimento de um comportamento, das escolhas lexicais, do vestiário, uma vez que aglutina valores e comportamentos de um estrato da sociedade, assim criando a sua própria linguagem e valores culturais para intera- gir com os interlocutores. Baseado nessas premissas, este artigo abordará : o histórico da análise do discurso, formação discursiva -dialogismo e ethos; o conceito de Música e o histórico do estilo Funk, com o propósito de analisar o corpus da música Créu - que contagia os adolescentes da periferia de São Paulo - por meio de um embasamento teórico de Mussalim (2005), Maigueneau (2004), Bakhtin (1992), Kerbrat-Orecchioni (1989), Amossy (2005) e Herschmann (2005).

\section{Histórico da análise do discurso}

A língua é analisada na estrutura interna em um sistema fechado, surgindo assim o estruturalismo. A análise do discurso cresce estruturada no Marxismo, juntamente com o desenvolvimento e crescimento da lingüística. De acordo com Mussalim (2005), a priori discurso significa qualquer coisa, pois toda produção de linguagem é um discurso.

A análise do discurso teve origem na França em 1960, neste momento, não considera a intenção do sujeito como algo determinante, porém os estudos pós 1960 demonstram que os sujeitos são condicionados por uma ideologia, sendo que analisar o discurso nada mais é que estudar a discursivização. Além disso, a análise do discurso trabalha com conceitos de formação discursiva, formação ideológica, heterogeneidade e interdiscurso, quer dizer, que a análise do discurso é 


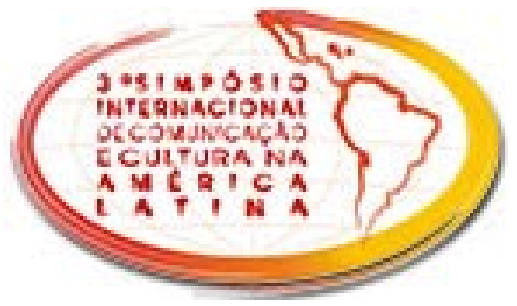

Sessão de Comunicações Coordenadas 02

Cultura, Cidadania e Mídias Alternativas

ancorado no Marxismo Althusseriano, na psicanálise lacaniana e na linguística estrutural. Sendo assim, de acordo com Maigueneau (2004 p. 21), "a análise do discurso supõe a colocação conjunta de vários textos, dado que a organização do texto tomado isoladamente não pode remeter senão a si mesmo (estrutura fechada) ou à língua (estrutura infinita).”.

\section{Dialogismo}

De acordo com Bakhtin (1992) a linguagem é dialógica, uma vez que a ciência humana possui método e objetos dialógicos, as idéias sobre o homem e a vida são marcadas pelo dialogismo, por isso Bakhtin (1992, p.35 apud Beth Brait1997, p.30) "a vida é dialógica por natureza."

\section{Ethos}

$\mathrm{O}$ ato de utilizar a palavra leva a construção de uma imagem de si. Não é preciso que o locutor faça seu auto-retrato, simplesmente o locutor faz em seu discurso uma apresentação de si, efetuase com freqüência à revelia dos parceiros, nas trocas verbais do cotidiano. Roland Barthes (1970, p.315) designa ethos como os traços de caráter que o orador mostra ao auditório com sinceridade ou não, contudo objetiva causar boa impressão. A construção da imagem dos interlocutores na obra de Michel Pêcheux (1969), onde é feita uma imagem um do outro, o emis- sor a faz uma imagem de si mesmo juntamente com seu interlocutor e de forma recíproca o receptor faz uma imagem do emissor e de si mesmo. Kerbrat-Orecchioni (1989) salienta que a imagem que fazem de si mesmos, do outro e aquela que imaginam que o outro faz deles. Nesse processo marca das competências não-linguísticas dos interlocutores que mostram a situação que forma o universo discursivo. Dominique Maingueneau (1993, p.138 apud AMOSSY 2005, p.31) salienta que o ethos não é dito claramente, porém mostrado:

o que o orador pretende ser, ele o dá a
entender e mostra: não diz que é simples
ou honesto, mostra-o por sua maneira de
se exprimir. O ethos está, dessa maneira,
vinculado ao exercício da palavra, ao papel
que corresponde a seu discurso, e noção
ao individuo real, independente de seu
desempenho oratório: é portanto o sujeito
da enunciação uma vez que enuncia que
está em jogo aqui.

O lugar onde aparece o ethos é o discurso, o logos do orador, mostra as escolhas feitas. Toda forma de se expressar, resulta da escolha entre diversas possibilidades lingüísticas e estilísticas. , Ruth Amossy lembra que Roland Barthes (1966, p.212 apud AMOSSY 2005, p. 70) sublinhou esta característica essencial: "são os traços de caráter que o orador deve mostrar ao auditório (pouco importando sua sinceridade) para causar boa impressão. [...] O orador enuncia uma informação e, ao mesmo tempo, ele 


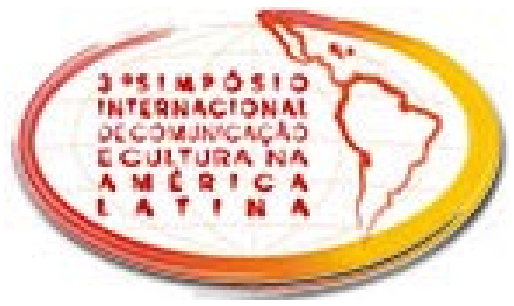

Sessão de Comunicações Coordenadas 02

Cultura, Cidadania e Mídias Alternativas

diz: eu sou isto, eu sou aquilo." O ethos está ligado ao ato de enunciação e o público constrói representações do ethos do enunciador antes que fale.

\section{Formação Discursiva}

De acordo com Maingueneau (2004, p.20 "formação discursiva é um conjunto de enunciados produzidos de acordo com esse sistema (a superfície discursiva". Sendo esse item (superfície discursiva) definido por Foucault (1995, p.135, apud MANINGUENEAU 2004, p.20) como discurso "um conjunto de enunciados na medida em que eles decorram da mesma formação discursiva... é constituído de um número limitado de enunciados para os quais podemos definir um conjunto de condições de existência."

Compreende-se que enunciado e formação discursiva estão intimamente ligados, principalmente das práticas discursivas que Foucault chama de práticas discursivas e que ele definiu assim: "um conjunto de regras anônimas, históricas, sempre determinadas no tempo e no espaço, que definiram, em uma dada época e para uma determinada área econômica, geográfica ou lingüística, as condições de exercício da função enunciativa". (FOUCAULT 1969 apud PAVEAU \& SARFARI, 2006, p.207)

\section{EXTRAPRENSA}

\section{Música}

A música não expressa uma idéia intelectual definida, tampouco um sentimento determinado, mas apenas aspectos psicológicos gerais, abstratos, (Schneider, 1957), porém essa generalidade não é uma abstração vazia, mas sim uma espécie de expressão com objetos divergentes que correspondem ao pensamento conceitual, por isso a música pode ser compreendida, interpretada e executada de diversas formas.

Para Richard Wagner (1813/ 1883), música é a linguagem do coração humano. O conceito de música diverge de cultura para cultura, embora a linguagem verbal seja uma forma de comunicar e de nos relacionarmos.

A música não é universal, já que cada povo possui sua maneira de expressão por meio da palavra. Então, a música possui uma linguagem universal, porém com dialetos que variam de cultura para cultura, envolvendo a maneira de tocar, cantar, organizar os sons e definir as notas básicas juntamente com seus intervalos. Ela está vinculada às emoções e ao mundo pré- verbal, tem uma linguagem privilegiada, já que por intermédio da música os seres humanos se comunicam e até dialogam com os cosmos, objetivando viajar pelo espaço com um disco de bronze banhado de ouro, levando o som da Terra.

EDIÇÃם ESPECIAL 


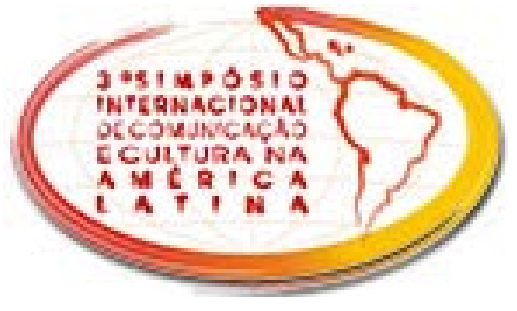

Sessão de Comunicações Coordenadas 02

Cultura, Cidadania e Mídias Alternativas

Em razão disso, Sagan (1983 p.287, apud JEANDOT 2008 p.13) postula que "a música delicada de muitas culturas, algumas delas expressando nossa sensação de solidão cósmica, nosso desejo de terminar o isolamento, nossa vontade de estabelecer contato com outros seres no Cosmos".

No entanto, quando um ser humano toca determinado instrumento ,cria um gesto, por isso controla o som, já que a palavra cantada amplia de forma significativa o vigor da linguagem falada. Enfatiza ,Stockhausen (1971, p. apud JEANDOT 2008 p.18) dizendo que a música é

determinada pelos músculos: os da laringe
para o canto, os dos dedos para os instru-
mentos, os da respiração para os instru-
mentos de sopro, tudo é determinado pelo
corpo do homem e é por isso que nunca
se tocou segundo ritmos mais rápidos ou
mais lentos ou mais lentos que os naturais
do corpo."

Percebemos assim, que a música não surgiu das reflexões de Pitágoras, tampouco de estudos das cordas ou das lâminas que vibram; é simplesmente resultado de extensas e infinitas vivências do indivíduo com a música e de civilizações musicais diversas. Por conseguinte, AGUIAR J. P 1998 diz que:

"a canção, tal como conhecemos hoje, existe há bastante tempo". Uma de suas características foi a de ser música produzida no meio popular e para ele especialmente dirigida.
(...) Contudo, é pela antiga combinação letra \& música que a canção melhor define. Quando pensamos em música popular,logo nos vem à mente a imagem de um cantor.(...)As palavras da letra servem para fixar a melodia na memória.Saber cantar as canções é um dos prazeres do ouvinte,e isto só é possível graças à presença da letra combinada à música. ““”

\section{Estilo Funk}

O termo funk ou funky surgiu na virada da década de 60 para 70, deixando de lado a conotação negativa para tornarse símbolo de alegria, de orgulho negro. No mercado o soul marca presença, então, alguns músicos da época começaram ver o funky apenas como uma verdente da música negra, capaz de elaborar uma música revolucionária, direcionada para a minoria étnica, já que os guetos de Nova York, aparecia um tipo de som com a intenção de transformar o cenário da música negra.

A origem do funk carioca foi no início dos anos 70, com os Bailes da pesada promovidos por Big Boy e Ademir Lemos. A equipe Soul Grand Prix iniciou a nova fase dos ritmos funky no Rio de Janeiro. O rapper Nelson na década de 80 trouxe o ritmo para a Praça da Sé, em São Paulo iniciou embasado na música negra norte- americana, que faziam referência às políticas raciais e culturais, que eram incompreendidas pelos funkeiros nacionais.

EDIÇÃa ESPECIAL 


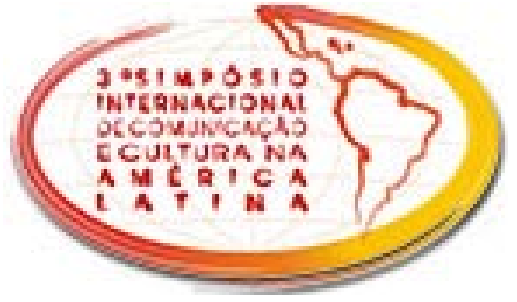

Sessão de Comunicações Coordenadas 02

Cultura, Cidadania e Mídias Alternativas

Então foi se nacionalizando e se distanciando do hip- hop, porém parte de juventude negra que era mais politizada continuou a fidelidade. Agora, no Rio, o conteúdo, o ritmo, foi traduzido em forma de música dançante, alegre e não tanto politizada. Já em São Paulo, o hiphop foi firmado pelo discurso político que fazia reivindicações do movimento negro.

Na década de 90, o funk e o hiphop se popularizavam e nacionalizavam em São Paulo e no Rio, onde funkeiros e b-boys distanciavam-se, surgindo uma dicotomia entre alienados e engajados, não porque o funk produzia uma música alegre, romântica e bem-humorada, possuía uma visão apolítica - por isso os funkeiros deixaram de ser bem- vindos nos demais bailes.Na verdade, o funk e o hip-hop não se iniciaram com os arrastões, mas isso pode ter causado a popularização. Verificando o contexto sociopolítico geral dos anos 90, percebe-se o clima de pânico que aterrorizou as principais cidades brasileiras, onde ocorreram arrastões, ou seja, ação conjunto de jovens, objetivando pegar o que podiam e a mídia acentuou essa sensação de medo.

Sendo assim, percebe-se que há um certo interesse dos jovens pobres pelo linguajar que apresenta (expressão artística), mas também como forma de protesto, de afirmações de valores, de significados e de etnicidades. Na primeira metade dos anos 90, ocorreram inúmeros noticiários, que chocaram a opinião pública como o assassinato de menores na Candelária, Chacina de Vigário Geral, arrastões Militares no Rio de Janeiro, massacre de Carandiru (SP), as invasões e os massacres dos sem-terra em várias localidades...

Nesse contexto, percebemos a violência na sociedade brasileira, há indício de uma desordem urbana, na verdade é uma maneira de expor a insatisfação pela estrutura autoritária e celetista, que gera a exclusão social, já que, a punição só ocorre para as camadas menos favorecidas da população, então a violência é uma forma de romper a ordem social. À medida que o funk foi se destacando na mídia, foi se identificando como atividade criminosa, uma atividade de gangue, que teve nos arrastões e na "biografia suspeita" dos que a integram a "contraprova" que acabam confirmando essa acusação.

Não é apenas a mídia que constituiu arena para o surgimento de discursos e sentidos divergentes. De acordo com Mikhail Bakhtin (1987), cada discurso comporta uma polissemia que não é controlada totalmente pelo sujeito.

Desta forma, o discurso nem sempre é traduzido num projeto ideológico do produtor. Percebe-se que o discurso que demoniza o funk é o mesmo que assenta a sua estrutura para o glamour. $\mathrm{O}$ 


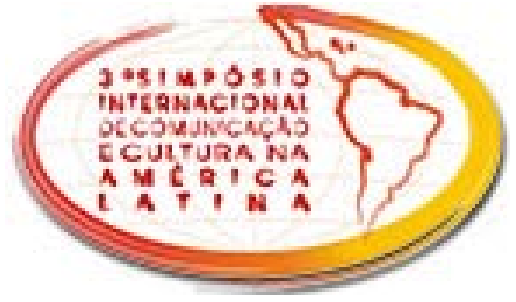

Sessão de Comunicações Coordenadas 02

Cultura, Cidadania e Mídias Alternativas

funk parecia seduzir os jovens carentes e da classe média, encontrando o caminho para o sucesso, dando uma perfeita visão de expectativa e frustrações. Desenvolvendo assim, seus próprios veículos de divulgação.

Com objetivo de ter imagens normalizadoras a mídia também possui limitações, mas também há frestas, brechas, onde surge o "outro", constituindo um lugar para se perceber as diferenças, denunciando condições e reivindicar a cidadania, desta forma, nota-se que os funkeiros constroem seus estilos nas ruas, desenvolvendo trajetórias e elaborando sentidos e territórios.

Atualmente o funk está muito apelativo, quer dizer, que um empresário opta por uma dançarina seminua rebolando. Anteriormente dança-se, fazia-se coreografias criativas, no entanto hoje, nos bailes há trenzinhos, pulando de um lado para o outro, os jovens em fila indiana, trazendo a mão sobre o ombro do companheiro da frente, como marca de solidariedade, segurança, proteção e recolhimento.

Além disso, há um exibimento grupal demonstrando competição e rivalidade entre os mesmos, o baile possui uma dimensão erótica, onde ocorrem movimentos corporais que simulam atos sexuais. $\mathrm{Na}$ verdade esse ambiente produzido pelo funk é visivelmente masculi- no, mas é claro que a presença feminina é fundamental para descontrair o baile, objetivando a criar competição entre os rapazes.

As coreografias dos homens são mais expansivas, com movimentos largos e jogo de pernas e braços metrificados, já as mulheres apresentam movimentos sinuosos, porém não deixam de uma base mais mecânica, produzindo movimentos retos. Enquanto os homens dançam sozinhos ou em grupo, os passos são sincronizados. Em contrapartida, as mulheres geralmente dançam em duplas ou em grupos pequenos com movimentos iguais opostos.

O ritual de violência nos bailes funk, os grupos não objetivam eliminar o inimigo, mas sim, almejam reconhecimento de um lugar, um território, nesse jogo, almeja a participação, a inclusão compensando seu cotidiano onde são rejeitados e excluídos. Esses grupos oriundos de segmentos populares, transitam na mídia numa espécie de jogo de espelhos, que ora os associa a imagens de delinqüência, ora os apresenta como uma expressão da cultura popular dos anos 90 .

Percebemos então, que ofunk tem impressionado muito pela força que possui, e a capacidade de permanecer presente, de se disseminar pelas localidades. O funk é considerado perigoso porque 


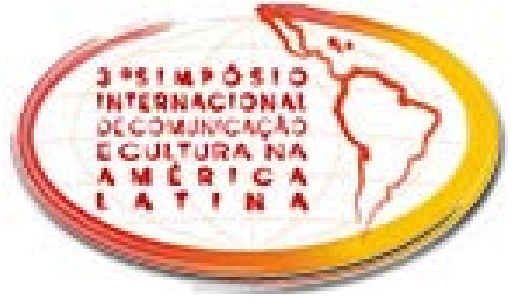

Sessão de Comunicações Coordenadas 02

Cultura, Cidadania e Mídias Alternativas

traduz uma conduta inconseqüente, que glorifica a delinqüência.

O estilo de vida desses jovens, quer dizer, os produtos culturais, gostos, opções de entretenimento, dança, roupas tem como principio estético "pegue e misture". Em outras palavras é uma maneira de chantagear as estruturas de dominação, por isso, elaboram valores, sentidos, identidade e afirmam localismos, e ainda se integram cada vez mais no mundo globalizado. Contudo, os funkeiros não sabem explicar ao certo como as coreografias se consagraram, uma vez que é um processo de criação natural, espontâneo. Ressaltam que algumas músicas são elaboradas a partir de uma dança, já outras vezes, a letra da música sugere construção de passos de dança e novas brincadeiras.

E quando estão distantes de seu território de origem (favelas e bairros pobres) sentem-se mais frágeis, porém mais engajados em lutar por um lugar, um reconhecimento. É claro que isso não ocorre somente pela dança e certas práticas sociais, já que a música está presente nos momentos de lazer, formando assim o lócus público, podemos assim afirmar e intervir de forma crítica no espaço público, mostrando um discurso próprio das favelas e subúrbios para toda a cidade.

Tendo como base o arcabouço teórico discutido nos itens anteriores: dialogismo, ethos, música e o estilo funk. Pretende-se, no próximo item, analisar a corpus da música "Créu".

\section{Análise do Corpus}

É créu é creu neles é créu nelas. Bora que vamos, bora que vamos. Pra dançar créu tem que ter disposição Pra dançar créu tem que ter habilidade Pois essa dança ela não é mole não Eu venho te lembrar são cinco velocidade

A primeira é devagarzinho,

É só aprendizado hein

É assim o...

Creeeuuu, creeuuu, creeeuuu.

Se ligou........... de novo...

Creeeuuu, creeeuuu, creeeuuu

Número dois:

Creeuu , creeuu , creeuu ,creeuu ,creeuu , creeuu ,continua...

Fácil né...de novo

Creeuu ,creeuu ,creeuu,

creeuu, creeuu ,

creeuu

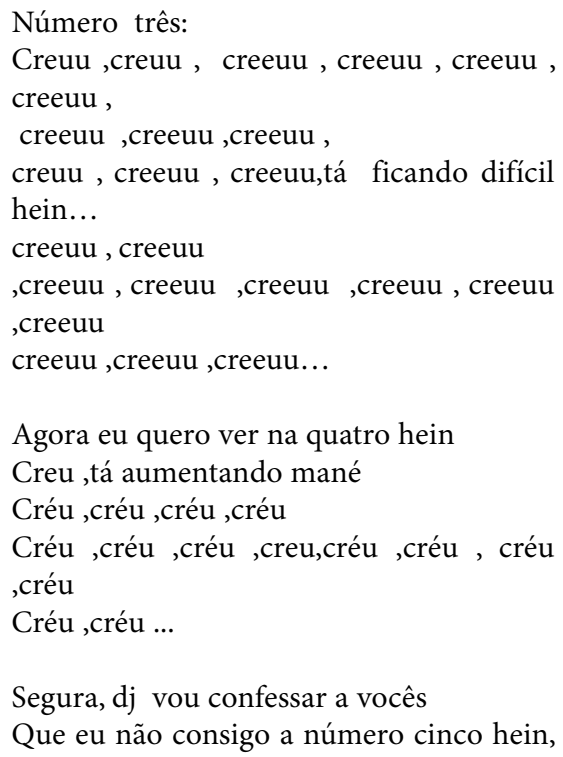




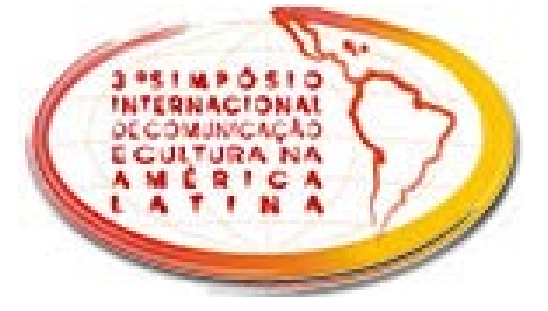

Sessão de Comunicações Coordenadas 02

Cultura, Cidadania e Mídias Alternativas

\author{
dj \\ Número cinco hein, dj \\ velocidade cinco na dança do creeuu... \\ créu, créu ,créu ,créu ,créu, créu ,créu, \\ créu, \\ créu ,créu, créu, \\ créu ,créu, créu ,créu, créu, créu ,créu, \\ créu, \\ créu créu créu, \\ créu ,créu ,créu, créu, créu, créu, créu,créu \\ créu, crêu, créu , \\ créu ,creu, créu ,créu ,créu ,créu ,créu, \\ créu \\ créu, créu ,créu , \\ créu ,créu ,créu ,créu ,créu ,créu ,créu, \\ créu, \\ créu ,créu, créu , \\ créu... \\ hahahahaha... \\ créu ,créu, créu, créu ,creu, créu ,créu \\ ,créu, \\ créu, créu, créu, \\ créu, créu, créu ,créu ,créu ,créu, créu \\ ,créu, \\ créu, créu ,créu, \\ créu, créu ,créu ,créu ,créu, créu, créu \\ ,créu \\ créu créu créu \\ créu ,créu, créu ,créu ,créu ,créu, créu \\ ,créu \\ créu,créu, créu \\ créu ,créu ,créu ,créu,créu ,créu ,créu ,créu \\ créu ,créu ,créu \\ créu...
}

A música inicia-se com um diálogo entre um enunciador que é o cantor, que faz uma convocação ao enunciatário que são os jovens funkeiros. Lembrando que segundo Bakhtin (1929/1988) considera que a língua é formada pelo fenômeno social da interação verbal, uma vez que o ser humano é inconcebível distante das relações que o ligam ao outro.
Esses jovens formam a base da sociedade que almejam diversão e reconhecimento, já que vivem numa sociedade injusta, e a grande massa humana vive em condições miseráveis, em morros e favelas, já que a política é essencialmente concentrada na renda, sendo que a topografia e a cronografia dessa cenografia é um baile, num centro urbano, cujo estilo de vida desses jovens é similar, visto que conota uma forma de auto-expressão, envolvendo o corpo, as roupas, o discurso, os entretenimentos de lazer. Engloba a produção cultural do grupo, formando assim, o ethos dos funkeiros, salientando que os mesmos constroem seu estilo nas ruas, em especial nas de terra batida, nas praias e principalmente nos bailes, desenvolvem trajetórias, elaboram-se sentidos e territórios. A noção de ethos retomada por Oswald Ducrot ( 1984, p 193, apud AMOSSY 2005, p.121) assevera:

em minha terminologia, diria
que o ethos é ligado a L, o locu-
tor enquanto tal: é como fonte da
enunciação que ele se vê dotado
de certos caracteres que, em con-
seqüência, tornam essa enunciação
aceitável ou recusável. O que o
orador poderia dele dizer, como
objeto da enunciação, concerne,
em contrapartida [...].ao ser do
mundo,e não é este que está em
questão na parte da retórica de
que falo.

Quando o enunciador diz:

É créu é creu neles é créu nelas. Bora que vamos, bora que vamos. 


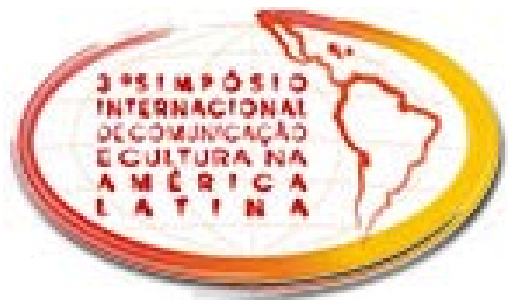

Sessão de Comunicações Coordenadas 02

Cultura, Cidadania e Mídias Alternativas

Há uma imbricação por parte do enunciador (cantor) direcionando ao enunciatário (platéia), neste momento ocorre uma espécie de ritual social da linguagem implícito, que é compartilhado pelos interlocutores. Quanto ao léxico créu, cujo significado contextual obtém possivelmente a seguinte definição: onomatopéia de conotação sexual, que supostamente corresponde ao som ou ruído no momento da conjunção carnal, que simula um movimento.

Seguindo a música com o léxico "bora", que é um mecanismo de interação com o locutor, que gramaticalmente de acordo com Celso Cunha (2007 p. 83/105) é uma palavra cuja composição é formada por aglutinação, (em+boa+hora), resultando embora. O autor pondera que:

\footnotetext{
chama-se formação de palavras o conjunto de processos morfossintáticos que permitem a criação de unidades novas com base em morfemas lexicais. Utilizam -se assim,para formar as palavras,os afixos de derivação ou os procedimentos de composição,que consiste em formar uma nova palavra pela união de dois ou mais radicais.
}

Sendo assim, no discurso houve um apagamento do prefixo "em", restando apenas" bora". Esse enunciador manifesta seu discurso, fazendo um convite persuasivo ao enunciatário,que de acordo com, Maingueneau (2007 p.17 apud BRUNELLI 2008, p.11) “...é um sistema de regras que define a especificidade de enunciação". Percebe-se que existe um comportamento intencional por parte do enunciador em liderar a platéia, há um jogo que é constituído pelos atos de fala,os quais demonstram convenções que regulam as relações entre sujeitos,dando a cada elemento um estatuto na atividade da linguagem,sendo assim, acaba ocorrendo um contrato,que de acordo com Charaudeau (1983 p. 50 apud MAINGUENEAU 1997, p.30)

\footnotetext{
... pressupõe que os indivíduos pertencentes a um mesmo corpo de práticas sociais sejam capazes de entrar em acordo a propósito das representações de linguagem destas práticas. Consequentemente, o sujeito que se comunica sempre poderá, com certa razão, atribuir ao outro (o não -EU) uma competência de linguagem análoga à sua que o habilite ao reconhecimento. $\mathrm{O}$ ato da fala transforma-se então ,em uma proposição que o EU dirige ao TU e para a qual aguarda uma contrapartida de conivência ."
}

Levando isso em consideração, um sujeito ao enunciar demonstra um ritual social da linguagem implícito, que naturalmente é partilhado pelos interlocutores. $\mathrm{Na}$ verdade os atos da fala fornecem credibilidade às enunciações do cantor que afirma o seguinte:

\footnotetext{
Pra dançar créu tem que ter disposição Pra dançar créu tem que ter habilidade Pois essa dança ela não é mole não Eu venho te lembrar são cinco velocidades
} 


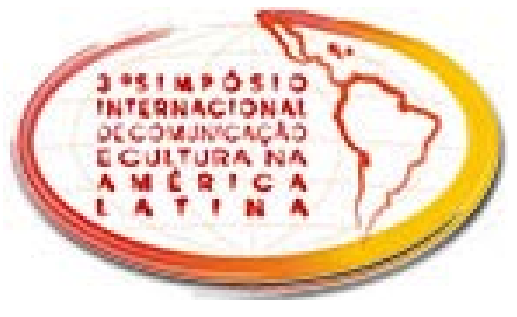

Sessão de Comunicações Coordenadas 02

Cultura, Cidadania e Mídias Alternativas

A subjetividade enunciativa constitui o sujeito (cantor) e o assujeita, segundo Maingueneau (1997) dandolhe autoridade, é claro que a encenação (seqüência musical) não é uma máscara do real, já que este real é investido pelo discurso do enunciador quando diz: é necessário ter "disposição"," habilidade," já que" não é mole não". Ocorre a, heterogeneidade constitutiva, visto que procura explicitar ao outro (platéia) por meio do discurso, salientando essas hipóteses. Depois, há um reconhecimento por parte da platéia, que aceita e vibra com o enunciado do cantor, devido a autoridade que possui no discurso relatado. Isso ocorre devido à formação discursiva, a qual está escrita o enunciador pelo seu caráter, que de acordo com Maingueneau (1997, p.47) "corresponde a este conjunto de traços psicológicos que o leitor-ouvinte atribui espontaneamente à figura do enunciador em função de seu modo de dizer". Salienta Foucault (1995), que esse sujeito traz e por isso demonstra suas experiências.

O enunciador ao afirmar isso, utiliza um tom, alegre, e variado, já que assevera Bakhtin (1992:396 apud BRAIT p33. 1997) “o tom não é determinado pelo material do conteúdo do enunciado ou pela vivência do locutor, mas pela atitude do locutor para com a pessoa do interlocutor (a atitude para com sua posição social, para com sua importância...)". Por isso, a platéia espontaneamente compre- endeu, que o cantor tinha o objetivo de salientar o erotismo, já que o funk assume a condição de invenção e potencializa essa tradição do pegue e misture,por isso Herchmann (2005, p.214) esclarece que o:

\begin{abstract}
estilo de vida e as práticas sociais dos grupos revelam um tipo de consumo e de produção que os desterritorializa e reterritorializa. A partir do funk esses jovens elaboram valores, sentidos, identidades e afirmam localismos, ao mesmo tempo em que se integram em um mundo cada vez mais globalizado. Ao construir seu mundo a partir do improviso, da montagem de elementos provenientes também de uma cultura transnacionalizada, em cima daquilo que está em evidência naquele momento, esses jovens, se não ressituam sua comunidade, amigos e a si mesmos no mundo, pelo menos denunciam a condição de excluídos da estrutura social..
\end{abstract}

Percebe-se, que há um certo convencimento por parte da platéia, ocorrendo assim, a eficácia discursiva advinda desse jogo de vozes. Primeiramente o cantor lembra, depois afirma, que são cinco velocidades:

\footnotetext{
A primeira é devagarzinho,

É só aprendizado hein

É assim o...

Creeeuuu, creeuuu, creeeuuu

Se ligou.......... de novo...

Creeeuuu , creeeuuu , creeeuuu
}

Nessa enunciação, ocorre uma ordem por parte do enunciador, que espera uma atitude responsiva da platéia. A formação discursiva fornece uma 


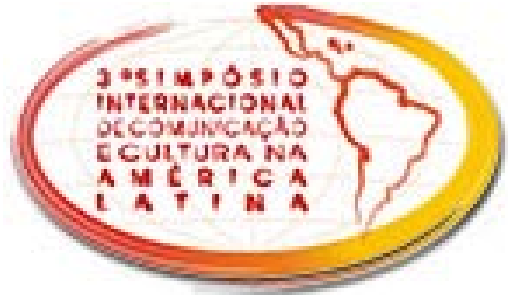

Sessão de Comunicações Coordenadas 02

Cultura, Cidadania e Mídias Alternativas

certa corporalidade ao enunciador, e essa corporalidade que de acordo com Maingueneau,(1997) possibilita aos sujeitos a incorporação de esquemas ,que definem a maneira específica de praticar o ato, incorporando assim, uma dimensão erótica, realizando movimentos corporais,visto que, de acordo com Maingueneau, (1997,p.40) "a formação discursiva na qual inscreve,o enunciador poderá jogar com estas coerções, ou pelo menos,realizar escolhas significativas entre as múltiplas possibilidades que se lhe oferecem".

$\mathrm{Na}$ seqüência musical, ocorre a repetição das vogais (e/u) na palavra créu, conforme um eco, almejando indicar a intensidade do ato, pois procura mostrar o prolongamento gestual,seguindo assim a enumeração:

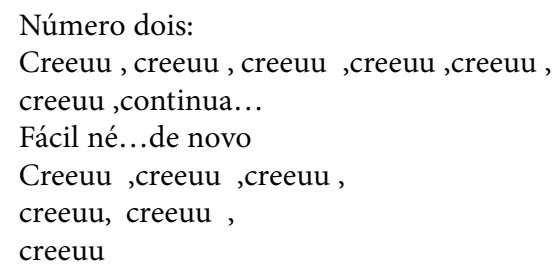

No baile provavelmente é tudo pura emoção. Há meninos e meninas de todos os estilos, circulam intensamente, ocorrendo uma grande proximidade de corpos. As meninas geralmente trajam shortinhos e saias curtíssimas, (algumas jovens um pouco mais velhas, vestem calças jeans, de moletom ou lycra) acompanhados de um top. Já os meninos, boné, bermudão, blusão, calça jeans ou moletom e camisa de malha, às vezes com mangas rasgadas. Baseado nesses fatos, Hermano Vianna (1997 apud HERSCHMANN, 2005, p..25) ressalta que: "tudo podia ser funky: uma roupa, um bairro da cidade, o jeito de andar e uma forma de tocar música que ficou conhecida como funk". Quanto às coreografias dos homens são mais expansivas, com movimentos largos e jogos de pernas e braços metrificados, já as mulheres apresentam movimentos sinuosos, porém retos. Vejamos a próxima enuneração:

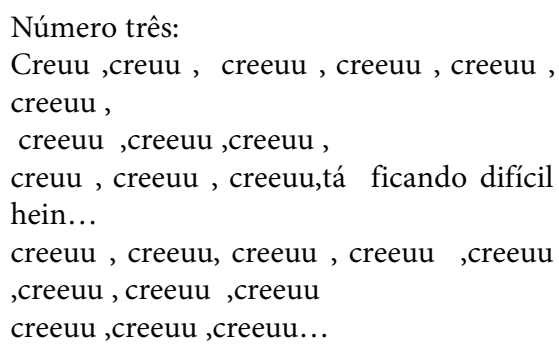

O enunciador determina uma atividade, um movimento, uma ação e exige da platéia uma atividade responsiva, demonstrando assim, a heterogeneidade mostrada, que é uma tentativa do sujeito ,o qual é representado pelo (cantor), pois procura explicitar a presença do outro, harmonizando essa presença, a qual aparece na música. Lembrando que pertencer ao mesmo grupo, obriga a acreditar no discurso, uma vez que a enunciação não é uma cena ilusória, onde se diz algo que é elaborado em outro lugar, mas sim, um dispositivo da construção do sentido 


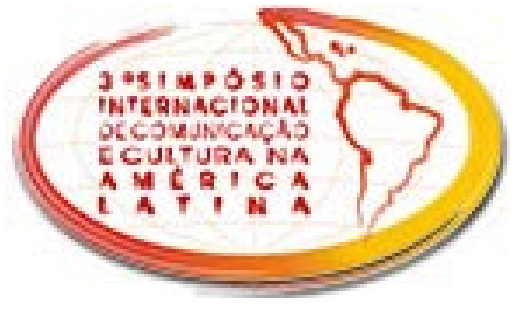

Sessão de Comunicações Coordenadas 02

\section{Cultura, Cidadania e Mídias Alternativas}

e dos sujeitos que se reconhecessem na música.

$\mathrm{Na}$ verdade, o sujeito é clivado (Lacan, 1998), já que não decide sobre os sentidos do discurso e suas possibilidades enunciativas, porém ocupa um lugar na sociedade, onde simplesmente enuncia com fundamentos ideológicos. Por isso Althusser(1970 apud MUSAALIM 2005,p.110) assevera que:"a ideologia é bem um sistema de representações. Mas estas representações não tem, na maior parte do tempo, nada a ver com a consciência, elas são na maior parte das vezes imagens, às vezes conceitos, mas se impõem a maioria dos homens, sem passar por suas consciências.”

Dessa forma, o sentido desse discurso é demarcado e preestabelecido pela identidade de cada um: o cantor e a platéia, nesse espaço interdiscursivo. $\mathrm{O}$ sentido da música vai se construindo a medida que o discurso foi se formando, logicamente que embasado na formação ideológica que de acordo com Maingueneau (2008, p.206):

a enunciação, ao se desenvolver, esforça-se por instituir progressivamente seu próprio dispositivo de fala. Ela implica,portanto,um processo de enlaçamento paradoxal.(...) Assim a,a cenografia é ao mesmo tempo,origem e produto do discurso;ela legitima um enunciado que, retroativamente,deve legitimá-la e fazer com que essa cenografia da qual se origina a palavra seja precisamente a cenografia requerida por tal discurso.
Na seqüência musical temos:

\author{
Agora eu quero ver na quatro hein \\ Creu ,tá aumentando mané \\ Créu ,créu ,créu ,créu \\ Créu ,créu ,créu ,creu,créu ,créu , créu \\ ,créu \\ Créu ,créu ...
}

Aqui, a dêixis coordena o espaço-temporal, articulando o eu e tu/aqui e agora. Onde o locutor discursivo do público, a topografia (aqui -no baile) e a cronografia (agora). Que de acordo com Maingueneau (1997, p..41)

"a dêixis define as coordenadas espaço-temporais implicadas em um ato de enunciação (...) possui a mesma função, mas manifesta-se em um nível diferente: o do universo de sentido que uma formação discursiva constrói através de sua enunciação (...) distinguir-se-á nesta dêixis o locutor e o destinatário discursivos, a cronografia e a topografia."

O sujeito constrói a cenografia de sua autoridade enunciativa. Por isso Maingueneau (2008,p.205) ressalta que:

o discurso impõe sua cenografia, de algum modo, desde o início; mas, por outro lado, é por intermédio de sua própria enunciação que ele poderá legitimar a cenografia que impõe." Em uma cenografia, associamse a figura do enunciador e figuras correlatas de co-enunciadores. Esses lugares supõem igualmente uma cronografia(um momento)e uma topografia(um lugar) das quais o discurso pretende originar-se(a cronografia e a topografia não são tempos cronológicos nem espaços geográficos,mas tempos e espaços ideológicos,históricos: a favela,a cidade, a civilização ,a globaliza- 


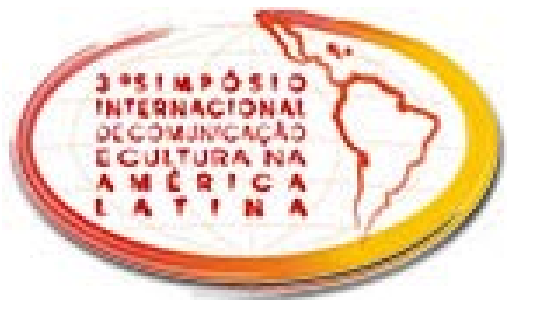

Sessão de Comunicações Coordenadas 02

\section{Cultura, Cidadania e Mídias Alternativas}

ção).

Baseando-se nisso, o enunciador determina para si e para o destinatário uma enunciação legítima, neste momento aparece no enunciado (música) uma terceira pessoa, a qual o sujeito (cantor) dirige-se ao público interpelando como mané, que de acordo com o verbete do minidicionário Aurélio (2000 p.443) significa indivíduo inepto, desleixado, tolo e bobo. Na progressão musical, impele ao dj que não prossiga, porque demonstra insegurança quando diz:

Segura, DJ vou confessar a vocês

Que eu não consigo a número cinco hein, dj

Número cinco hein, dj

velocidade cinco na dança do creeuu...

créu, créu ,créu ,créu ,creu, créu ,creu,

créu,

créu, creu, creu,

créu ,creu, créu ,creu, creu, créu ,creu, créu,

créu créu creu,

créu ,créu ,creu, creu, creu, creu, creu,créu

créu ,crêu, créu ,

créu ,creu, créu ,créu ,créu ,créu ,creu, créu

creu, créu ,créu ,

créu ,créu ,créu ,créu ,créu ,créu ,creu, creu,

créu ,creu, créu,

créu...

hahahahaha...

créu ,creu, creu, créu ,creu, créu ,créu ,creu,

créu, creu, creu,

créu, créu, créu ,créu ,créu ,creu, créu ,créu,

créu, créu ,créu ,

creu, créu ,créu ,créu ,creu, creu, créu

\author{
,créu \\ créu créu créu \\ créu ,creu, créu ,créu ,créu ,creu, créu \\ ,créu \\ creu,creu, créu \\ créu ,créu ,créu ,creu,créu ,créu ,créu ,créu \\ créu ,créu ,créu \\ créu...
}

Lembrando que de acordo com Herschmann (2005, p.287) "DJ é discotecário, é quem comanda o som e, por conseguinte, o baile". O cantor (enunciador) dirige-se ao público (platéia) por meio de seu discurso, salientando a pressuposição, que não vai conseguir realizar a número cinco, demonstrando assim, uma refutação proposicional. Sendo que a velocidade da dança poderá atingir o ápice, que dizer, o êxtase. Por isso assevera Kerbrat-Orecchioni (1978, p.56 apud POSSENT 2008 p.79) o seguinte que; "toda asserção é assumida, explícita ou implicitamente por um sujeito enunciador e é para este sujeito, em primeiro lugar que ela é verdadeira".

No entanto, para expressar toda a velocidade e êxtase nesta cena, o cantor pronuncia ininterruptamente a palavra créu, totalizando, 113 vezes, pronunciada num tom de autoridade e satisfação, transparecendo assim, a heterogeneidade mostrada, que de acordo com AuthierRevuz,(1982 apud MUSSALIM, 2005 p.134) “é uma tentativa do sujeito de explicitar a presença do outro no fio discursivo, numa tentativa de harmonizar as diferentes vozes que atravessam o seu 


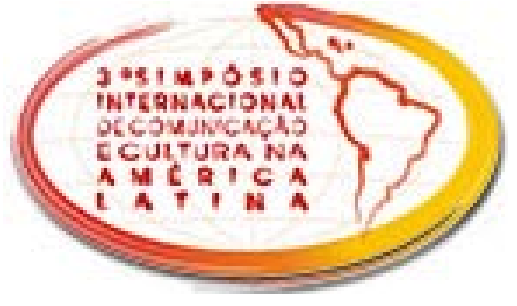

Sessão de Comunicações Coordenadas 02

Cultura, Cidadania e Mídias Alternativas

discurso, numa busca pela unidade, mesmo que ilusória".

\section{Considerações Finais}

Dado o exposto, podemos perceber que a Análise do Discurso com fulcro nos critérios da linha francesa, estuda as produções verbais baseadas nas condições sociais de produção, sendo essas consideradas integrantes na significação e modo de formação dos discursos. Por isso nos remetemos ao dialogismo, que origina da interação verbal estabelecida entre o enunciador e o enunciatário, aparecendo a relação eu-tu, que nos conduz para o subjetivismo, conclui-se ocorrer um deslocamento do conceito de sujeito,o qual perde o papel principal ,sendo substituído por divergentes vozes sociais que fazem dele um sujeito histórico e ideológico.

Esse sujeito contribui para a formação do ethos, que está ligado ao estatuto do locutor e à questão de sua legitimidade, quer dizer, ao processo de legitimação pela fala, sendo que ato de utilizar a palavra leva a construção de uma imagem de si, pois o locutor faz em seu discurso uma apresentação de si.

Partindo dessa premissa, percebemos a construção do ethos do enunciador na música analisada (Creu), juntamente com o enunciatário que é o fiador, embasado na ampliação do nosso conhecimento de mundo sobre o estilo funk que simplesmente invadiu a cena cultural no Brasil, seduzindo o jovem em paulistano por possuir um ritmo sincopado, que é levado por guitarras ,um baixo denso, a presença marcada por metais e percussão, uma rítmica forte devido ás batidas mais vigorosa e dançante, e por conseguinte é acompanhado por modernas melodias. Devido a isso tem se consolidado como expressão artística, mas também como meio de protesto, de afirmação de valores, significados e etnicidades.

Sendo assim, pode-se depreender que a sociedade atualmente possui diversas etnias e valores culturais, por isso cabe ao analista do discurso recuperar as formas de materialização,mostrando os efeitos de sentido,fazendo os recortes e analisando os planos de forma global. 


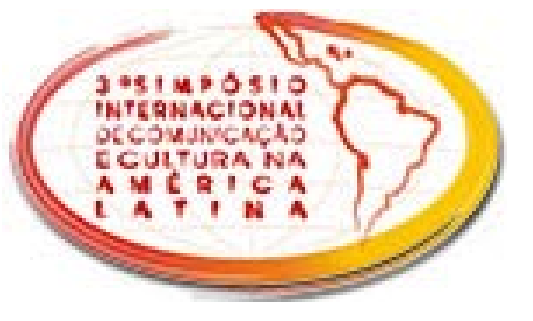

Sessão de Comunicações Coordenadas 02

Cultura, Cidadania e Mídias Alternativas

\section{Referências bibliográficas}

AGUIAR J. A poesia da canção. (s/l) Seccione. 1998

AMOSSY, R. Da noção retórica de ethos à análise do discurso in: AMOSSY, R. (org.) Imagens de si no discurso: a construção do ethos. São Paulo: Contexto, 2005, p. 928.

O ethos na intersecção das disciplinas: retórica, pragmática, sociologia dos campos in: AMOSSY, R. (org.) Imagens de si no discurso: a construção do ethos. São Paulo: Contexto, 2005, PP. 119-144.

Imagens de si no discurso: a construção do ethos, São Paulo, Contexto: 2005.

ARROYO, M.G. Ofício de Mestre, Petrópolis: Vozes, 2000.

BRAIT, B (org). Dialogismo e construção do sentido. Campinas: UNICAMP, 1997. BRUNELI, A. F. Notas sobre a abordagem interdiscursiva de Maingueneau. POSSENTI, S. e BARONAS , R. L. (orgs.) Contribuições de Domenique Maingueneau. para Análise do Discurso do Brasil. São Carlos: Pedro \& João Editores, 2008, p.13-26.

CUNHA C. CINTRA, L.F.L. Nova gramática do português contemporâneo. $3^{\mathrm{a}}$ edição. Rio de Janeiro, 2007.

COPLAND A. Como ouvir e entender música. Editora: Arte nova S.A, 1974.

CHALITA, G.B.I. O poder de fogo $d a$ educação in: Revista Fapesp, ed.85. São Paulo: março de 2003.

DIJK, T.A.V. Cognição, Discurso e Interação. São Paulo: Contexto, 2004.

\section{EXTRAPRENSA}

FERREIRA, A. B. H, Miniaurélio Século XXI Escolar: $O$ minidicionário da língua portuguesa. Rio de Janeiro: Nova Fronteira, 2000.

HERSCHMANN, M. O Funk e o HipHop invadem a cena, $2^{a}$ edição, Rio de Janeiro, Editora: UFRJ, 2005.

IMBERNÓN F. (org) A Educação no século XXI, Os desafios do futuro imediato. Porto Alegre, Editora: Artmed, 2000.

JEANDOT, N. Explorando o universo da música. São Paulo: Seccione, 1999.

JORDÃO, P. $A$ antropologia pós-moderna Uma nova concepção da etnografia e seus sujeitos. Disponível: <http: www.portalppg ci.marilia.unesp.br/ric/include/getdoc.php?> Acesso em 04/12/2009

MAINGUENEAU, D. Novas Tendências em Análise do Discurso, $3^{\mathrm{a}}$ ed. Campinas: Editora da Unicamp/Pontes, 1997.

. Gênese do Discurso, Editora: Cortez, São Paulo, 2004.

Ethos, cenografia, incorporação in: AMOSSY, R. (org.) Imagens de si no discurso: a construção do ethos. São Paulo: Contexto,2005,PP.69-92.

MARQUES I. A. Dançando na escola, 4. ed. São Paulo: Cortez, 2007.

MUSSALIM F. \& BENTES A. C. (orgs.) Introdução à lingüística domínios e fronteiras, São Paulo: Cortez. 2005.

PAVEAU, M. - A. \& SARFATI G. - É. $A s$ grandes teorias da lingüística, São Carlos: Claraluz, 2006.

POSSENTI, S. Um dispositivo teórico e metodológico in: POSSENTI, S; BARONAS , R. L. (orgs.) Contribuições de 
Domenique Maingueneau para Análise do Discurso do Brasil. São Carlos: Pedro \& João Editores, 2008, p. 201-212.

Novas Tendências, Cenas da Enunciação, São Carlos, 2008.

POSSENTI S. \& BARONAS R. L. (orgs.). Contribuições de Domenique Maingueneau para a Análise do Discurso do Brasil. São Carlos: Editores: Pedro \& João, 2008.

ZUBEN P. Música e Tecnologia: o som e seus novos instrumentos, Editores-Brasil, Irmãos Vitale, 2004.

\section{Notas}

${ }^{1}$ Essa concepção nos leva a defesa que postulou Evans-Ptrichard (1950) da antropologia como tradução para nossa cultura daqueles que são nossos sujeitos de pesquisa. 